\title{
Mesin Pemanggang Biji Kopi dengan Suhu Terkendali Menggunakan Arduino Due
}

\author{
Irwan Juniar Sasongko, Muhammad Rivai \\ Departemen Teknik Elektro, Fakultas Teknologi Elektro, Institut Teknologi Sepuluh Nopember \\ E-mail:muhammad_rivai@ee.its.ac.id
}

\begin{abstract}
Abstrak-Indonesia merupakan Negara yang menghasilkan produk berupa biji kopi baik mentah maupun dalam kemasan. Produk ini merupakan salah satu komoditas unggulan bagi pendapatan nasional Negara Indonesia. Banyak teknologi pemanggangan biji kopi yang telah dibuat, namun kebanyakan memanfaatkan energi listrik sebagai sumber pemanas sehingga meningkatkan biaya operasional. Pada penelitian ini telah dibuat mesin pemanggang biji kopi dengan suhu terkendali menggunakan arduino due. Mesin pemanggang didesain seperti oven yang memiliki 2 lapisan bagian dalam dan luar. Peralatan ini memanfaatkan kompor gas portable sebagai alat pemanas pemanggang kopi dan menggunakan sensor suhu RTD (Resistance Temperature Detector). Sensor suhu akan memberikan feedback pada sistem kontrol proportional yang akan menggerakkan motor servo sebagai pengatur besar kecilnya nyala api yang digunakan pada proses pemanggangan biji kopi. Mikrokontroler dipilih menggunakan arduino due karena memiliki kecepatan akses data yang cepat. Devais ini merupakan mikrokontroler ARM (Advanced RISC Machine) dengan keunggulan memiliki performa yang baik dan juga efisiensi daya dengan tegangan kerja mikrokontroler ARM sebesar 3.3Volt. Terdapat beberapa kecocokan nilai histogram RGB (Red Green Blue) dari hasil penyangraian biji kopi dengan kopi yang telah disangrai oleh seorang ahli. Hasil eksperimen menunjukkan bahwa tingkat kematangan biji kopi dapat ditentukan berdasarkan suhu akhir dari biji kopi $235^{\circ} \mathrm{C}$ untuk tingkat kematangan medium roast, dan $240^{\circ} \mathrm{C}$ untuk tingkat kematangan dark roast.
\end{abstract}

Kata Kunci - Arduino Due, Kompor gas, Pemanggang biji kopi, Sensor Suhu RTD.

\section{PENDAHULUAN}

$\mathrm{N}^{\mathrm{s}}$ EGARA Indonesia merupakan salah satu negara yang menghasilkan produk berupa biji kopi. Biji kopi yang dihasilkan baik mentah maupun dalam kemasan merupakan salah satu komoditas unggulan bagi pendapatan nasional negara Indonesia. Pada tahun 2015, ekspor dibagian perkebunan Negara Indonesia mencapai hingga US\$23.93 milyar. Tingkat ekspor biji kopi Negara Indonesia mencapai 502.201 ton atau setara dengan US\$ 1.197.735. Untuk import biji kopi hanya diangka 12.462 ton atau setara dengan nilai US\$ 31.492. Pada tahun 2016 ekspor biji kopi mencapai 267.058 ton atau setara dengan US\$ 650.216. Import biji kopi hanya mencapai angka 23.902 ton atau setara dengan nilai US\$ 45.117 [1].

Sektor perkebunan terluas penghasil biji kopi yang pertama adalah pulau Sumatera memiliki tingkat luas lahan sebesar 777.533 Ha dengan jumlah produksi mencapai 433.812 ton pertahun. Pada urutan ke-dua ialah pulau jawa memiliki luas lahan sebesar 143.603 Ha dengan produksi biji kopi 74.744 ton pertahun.

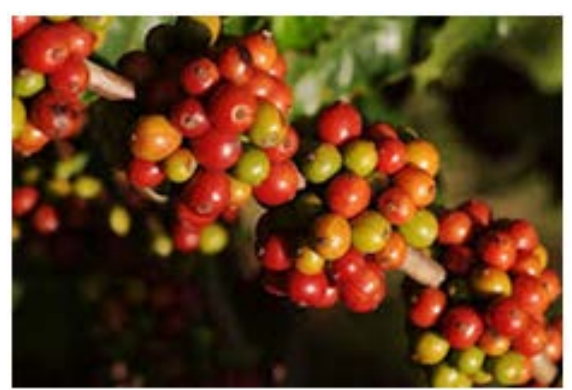

Gambar 1. Tanaman kopi.

Diurutan ke-tiga dari nusa tenggara memiliki luas lahan sebesar 113.448 Ha dengan produksi biji kopi 43.195 ton pertahun. Penghasil terbesar ke-empat dari Sulawesi memiliki luas lahan sebesar 112.618 Ha dengan produksi biji kopi sebesar 41.053 ton per-tahun. Sisanya dari pulau Kalimantan dan Maluku beserta papua [1]. Gambar 1 merupakan contoh tanaman kopi. Indonesia menghasilkan 93\% kopi robusta dan 7\% kopi arabika. Dinilai dari minat dan harga, kopi arabika lebih mahal dan juga banyak diminati. Pengolahan yang lebih baik pasca panen dapat menaikkan harga beli terhadap para petani di Indonesia [2].

Teknologi pemanggangan biji kopi saat ini menggunakan pemanas dengan energi listrik. Pada penelitian ini telah dilakukan modifikasi pada kompor gas portable sehingga dapat dimanfaatkan sebagai sumber panas untuk memanggang biji kopi sehingga tidak lagi tergantung pada sumber daya listrik [2]. Dengan adanya kendali suhu, maka sistem ini diharapkan dapat menghasilkan kematangan biji kopi yang lebih merata dengan kualitas yang konsisten.

\section{DASAR TEORI}

\section{A. Biji Kopi (Coffee Bean)}

Biji kopi pertama kali dikenal dan mulai dikonsumsi pada abad ke-9 di Ethiopia yang berlanjut ke Mesir dan juga Yaman. Pada abad ke-15 menyebar di daerah Armenia, Persia, Turki, dan Afrika utara. Tanaman kopi yang dikembangkan di Indonesia memiliki dua jenis yaitu biji kopi arabika dan biji kopi robusta. Biji kopi arabika adalah tanaman kopi yang berasal dari Ethiopia. Tanaman kopi arabika tumbuh pada ketinggian 700 hingga 1700 mdpl. Jenis kopi arabika merupakan yang paling banyak dicari oleh para penggemar minuman kopi karena rasanya yang dianggap paling enak. Biji kopi robusta adalah keturunan dari beberapa tanaman kopi yang ada. Tanaman kopi robusta tumbuh pada ketinggian 700 mdpl. 


\section{B. Tingkat Kematangan Kopi}

Tingkat kematangan biji kopi mempengaruhi karakter rasa dari minuman kopi terdapat macam-macam tingkat kematangan kopi yaitu light roast, medium roast, dark roast seperti yang ditunjukkan pada gambar 2 .

Pada tingkat kematangan light roast, rasa yang dihasilkan oleh minuman kopi cenderung asam. Aroma khas kopi yang dihasilkan pada tingkat kematangan ini kurang terasa. Tingkat kematangan light roast merupakan tingkat kematangan paling awal dengan ciri-ciri biji kopi mulai berubah warna coklat terang. Karena proses pemanggangan yang tidak terlalu lama, tingkat kematangan light roast juga dikategorikan dengan tingkat kematangan half city, cinnamon. Pada kondisi light roast, minyak yang dihasilkan kopi belum terlihat dan biji kopi memiliki karakter kering. Suhu pemanggangan biji kopi dengan kematangan light roast berada pada kisaran $180^{\circ} \mathrm{C}$ hingga $205^{\circ} \mathrm{C}$. Kematangan dengan tingkat light roast ditandai dengan terjadinya retakan pertama pada biji kopi [3].

Pada tingkat kematangan medium roast, rasa yang dihasilkan cenderung manis. Aroma pemanggangan kopi tercium sangat tajam. Pada tingkat kematangan medium roast ini sama dengan light roast biji kopi masih belum terlihat berminyak. Warna biji kopi mulai cenderung cokelat gelap.

Pada kematangan medium roast juga dikategorikan sebagai kematangan full city, full city+, Vienna full city++. Kematangan medium roast berkisar pada suhu $210^{\circ} \mathrm{C}$ hingga $230^{\circ} \mathrm{C}$ setelah retakan pertama dan sebelum retakan kedua terjadi. Pada tingkat kematangan ini, kandungan cafein pada biji kopi lebih rendah dibandingkan kematangan tingkat light roast. Kematangan pada tingkat inilah yang banyak digunakan.

Pada tingkat paling matang adalah dark roast atau juga bisa dikategorikan kematangan dengan tingkat french, nearly black. Biji kopi mulai berminyak dan warna biji kopi cenderung hitam. Rasa yang dihasilkan cenderung pahit. Kematangan pada tingkat ini berkisar pada suhu sekitar $240^{\circ} \mathrm{C}$ dengan ditandai retakan kedua yang terjadi pada biji kopi.

Kategori tingkat kematangan biji kopi tidak hanya terdiri dari tiga level kematangan. Jika dirincikan kembali pada tingkat kematangan light roast, medium roast dan dark roast. Pada tingkat kematangan light roast tergolong dalam kategori kematangan half city, cinnamon. Untuk medium roast tergolong dalam kematangan city, full city, full city+. Sedangkan untuk dark roast dikategorikan kedalam kematangan Vienna, full city++ [4], ditunjukkan pada Tabel 1. Dari data tersebut, first crack pada saat proses pemanggangan kopi terjadi ketika suhu mencapai $200^{\circ} \mathrm{C}$ hingga $210^{\circ} \mathrm{C}$ dan berakhir pada suhu $225^{\circ} \mathrm{C}$. Sedangkan second crack terjadi saat suhu telah mencapai $235^{\circ} \mathrm{C}$ hingga $240^{\circ} \mathrm{C}$ dan berakhir pada saat suhu telah mencapai $245^{\circ} \mathrm{C}$.
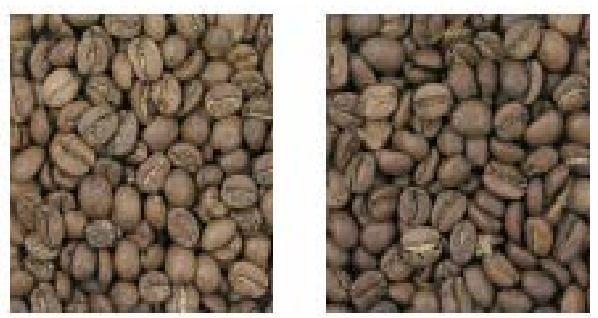

(a)

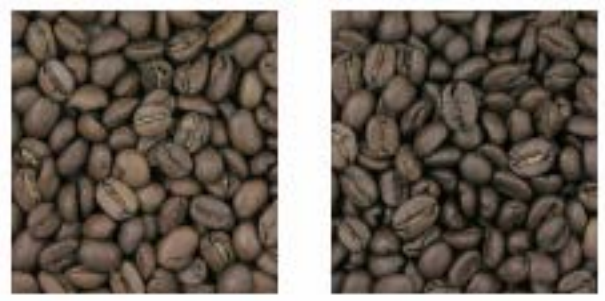

(b)

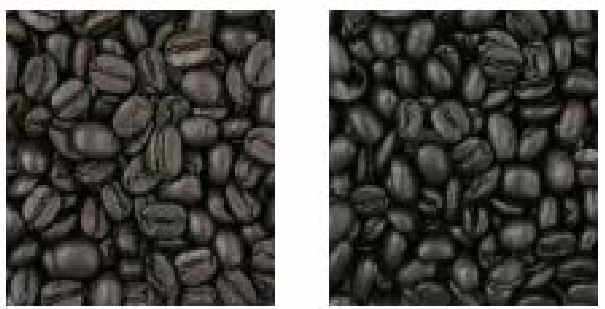

(c)

Gambar 2. Jenis pemanggangan kopi: (a) Light roast, (b) Medium roast, dan (c) Dark roast.

\section{Teknik Pemanggangan Biji Kopi}

Pemanggangan merupakan kunci penting proses produksi kopi. Faktor pemanggangan biji kopi yang tepat adalah dari suhu dan lama proses pemanggangan. Jenis biji kopi yang berbeda akan ikut mempengaruhi tingkat kematangan pada proses pemanggangan. Terlalu lama melakukan pemanggangan terhadap biji kopi akan berdampak timbulnya rasa pahit yang berlebihan [5].

Tidak ada aturan resmi mengenai cara pemanggangan biji kopi, setiap roaster memiliki cara sendiri-sendiri dalam memanggang biji kopi. Namun terdapat beberapa parameter yang perlu diperhatikan saat proses memanggang. Suhu menjadi salah satu faktor penentu tingkat kematangan. Untuk lebih akurat para roaster juga melakukan penginderaan aroma dan juga melihat warna secara manual saat proses pemanggangan [6][7][8].

\section{Arduino Due}

Arduino due digunakan sebagai perangkat yang memproses data yang dihasilkan sensor. Arduino due yang digunakan mengaplikasikan mikrokontroller AT91SAM3X8E ARM Cortex-M3 32-Bit. Kelebihan arduino due dibandingkan dengan arduino yang lain adalah kecepatan clock mencapai 84MHz. Arduino due dibekali dengan 54 pin input / output dengan 12 pin diantaranya mampu digunakan sebagai PWM (Pulse Width Modulation) dan 12 analog input dengan 2 DAC (Digital Analog Converter).

Tersedia 12 pin analog input diantaranya adalah pin A0 hingga A11. Pin tersebut terhubung dengan ADC (Analog Digital Converter) yang terdapat didalam mikrokontroler. Kisaran tegangan input yang disarankan mulai dari 7-12 Volt. Dengan menggunakan pin output PWM, arduino due digunakan sebagai pengendali putaran motor servo sebagai buka tutup katup gas pada kompor portable. Pin out PWM ini terletak pada pin 2 hingga pin 13. 
Tabel 1.

Tingkat kematangan biji kopi

\begin{tabular}{|c|c|c|c|c|c|c|c|c|}
\hline $\begin{array}{l}\text { Style of } \\
\text { Roast }\end{array}$ & $\begin{array}{l}\text { Roasted } \\
\text { Bean } \\
\text { Colour }\end{array}$ & $\begin{array}{c}\text { Bean } \\
\text { Surface }\end{array}$ & $\begin{array}{l}\text { Approx. Temp } \\
\text { of Bean at End } \\
\text { of Roasting }\end{array}$ & Acidity & Aroma & Sweetness & Body & Cracks during Roasting \\
\hline $\begin{array}{l}\text { Half } \\
\text { City }\end{array}$ & & Dry & $195 \mathrm{C}$ & $\begin{array}{l}\text { Very } \\
\text { High }\end{array}$ & Medium & Low & Thin & Just before $1^{\text {st }}$ Crack \\
\hline $\begin{array}{l}\text { Cinnam } \\
\text { on }\end{array}$ & & Dry & $200 \mathrm{C}$ & High & Strong & Low & $\begin{array}{l}\text { Thin to } \\
\text { Full }\end{array}$ & Start of $1^{\text {st }}$ Crack \\
\hline City & & Dry & $210 \mathrm{C}$ & Mediun & $\begin{array}{l}\text { Very } \\
\text { Strong }\end{array}$ & $\begin{array}{l}\text { Medium to } \\
\text { Strong }\end{array}$ & Full & Middle of $1^{\text {st }}$ Crack \\
\hline $\begin{array}{l}\text { Full } \\
\text { City }\end{array}$ & & Dry & $225 \mathrm{C}$ & Medium & $\begin{array}{l}\text { Very } \\
\text { Strong }\end{array}$ & $\begin{array}{l}\text { Medium to } \\
\text { Strong }\end{array}$ & $\begin{array}{l}\text { Very } \\
\text { Full }\end{array}$ & End of $1^{\text {st }}$ Crack \\
\hline $\begin{array}{c}\text { Full } \\
\text { City + }\end{array}$ & & $\begin{array}{c}\text { Dry to tiny } \\
\text { patches of oil }\end{array}$ & $230 \mathrm{C}$ & $\begin{array}{l}\text { Medium } \\
\text { to Low }\end{array}$ & Strong & $\begin{array}{l}\text { Medium to } \\
\text { Strong }\end{array}$ & $\begin{array}{l}\text { Very } \\
\text { Full }\end{array}$ & Between $1^{\text {st }}$ and $2^{\text {nd }}$ Crack \\
\hline $\begin{array}{l}\text { Vienna } \\
\text { or Ful } \\
\text { City ++ }\end{array}$ & & Shiny Surface & $235 \mathrm{C}$ & Low & $\begin{array}{l}\text { Medium } \\
\text { to Strong }\end{array}$ & $\begin{array}{l}\text { Medium to } \\
\text { Strong }\end{array}$ & Full & Start of $2^{\text {nd }}$ Crack \\
\hline Italian & & Shiny Surface & $240 \mathrm{C}$ & $\begin{array}{l}\text { Very } \\
\text { Low }\end{array}$ & Weak & Low & Thin & $2^{\text {nd }}$ Crack \\
\hline French & & Shiny Surface & $245 \mathrm{C}$ & Very & $\begin{array}{l}\text { Weak to } \\
\text { Almost } \\
\text { Burnt } \\
\text { Aroma }\end{array}$ & $\begin{array}{l}\text { Very Low } \\
\text { to None }\end{array}$ & $\begin{array}{l}\text { Very } \\
\text { Thin }\end{array}$ & End of $2^{\text {nd }}$ Crack \\
\hline $\begin{array}{l}\text { Nearly } \\
\text { Black }\end{array}$ & & Totally Shiny & $250 \mathrm{C}$ & $\begin{array}{l}\text { Very } \\
\text { Very } \\
\text { Low }\end{array}$ & $\begin{array}{l}\text { Burnt } \\
\text { Aroma }\end{array}$ & None & $\begin{array}{l}\text { Extreme } \\
\text { ly Thin }\end{array}$ & $2^{\text {nd }}$ Crack has totally ended, risk of fire \\
\hline
\end{tabular}

\section{E. Sensor RTD PT100}

RTD (Resistive Temperature Detector) PT100 merupakan sensor suhu dengan akurasi sekitar $0.39^{\circ} \mathrm{C}$, ditunjukkan pada pada tabel 2. Pengaplikasian sensor ini digunakan untuk mendeteksi perubahan suhu yang dikonversikan dalam bentuk hambatan. Penggunaan sensor RTD dengan jenis PT100 ini menggunakan bahan platinum dengan nilai hambatan sebesar $100 \Omega$ pada suhu $0^{\circ} \mathrm{C}$. Semakin tinggi suhu yang diterima oleh sensor maka semakin besar nilai hambatan yang akan dihasilkan. Sensor ini tergolong sensor pasif dikarenakan untuk menggunakannya dibutuhkan tegangan masukan dari luar. Sensor ini dapat digunakan pada suhu $-200^{\circ} \mathrm{C}$ hingga $650^{\circ} \mathrm{C}$ [10]. Kenaikan resistansi bahan sensor akan berbanding lurus dengan kenaikan suhunya, ditunjukkan pada Gambar 3

Tabel 2.

Parameter perbedaan deteksi bahan RTD

\begin{tabular}{ccccc}
\hline \hline Material & $\begin{array}{c}\text { Temp. } \\
\text { Coeff. }\end{array}$ & $\begin{array}{c}\text { Min. } \\
\text { Range }\end{array}$ & $\begin{array}{c}\text { Max. } \\
\text { Range }\end{array}$ & $\begin{array}{c}\text { Melting } \\
\text { Point }\end{array}$ \\
\hline Platinum & 0.39 & $\begin{array}{c}- \\
260^{\circ} \mathrm{C}\end{array}$ & $1100^{\circ} \mathrm{C}$ & $1773^{\circ} \mathrm{C}$ \\
Copper & 0.39 & $\begin{array}{c}0^{\circ} \mathrm{C} \\
-\end{array}$ & $180^{\circ} \mathrm{C}$ & $1083^{\circ} \mathrm{C}$ \\
Nikkel & 0.62 & $\begin{array}{c}- \\
220^{\circ} \mathrm{C}\end{array}$ & $300^{\circ} \mathrm{C}$ & $1455^{\circ} \mathrm{C}$ \\
Tungsten & 0.42 & $\begin{array}{c}{ }^{\circ} \\
200^{\circ} \mathrm{C}\end{array}$ & $1000^{\circ} \mathrm{C}$ & $3380^{\circ} \mathrm{C}$ \\
\hline \hline
\end{tabular}

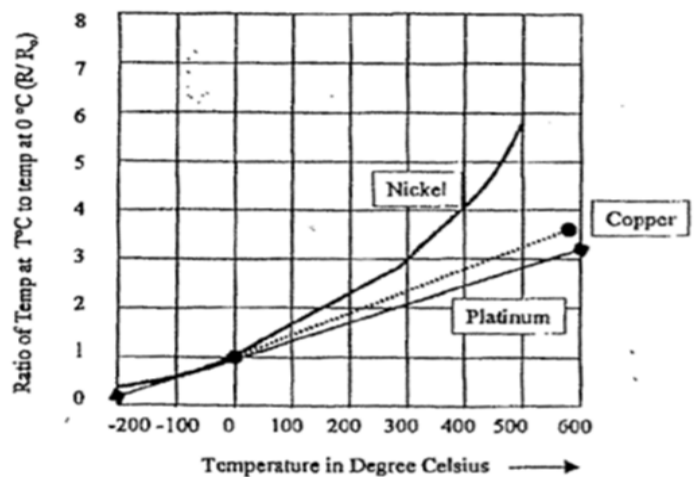

Gambar 3. Grafik perbandingan bahan RTD.

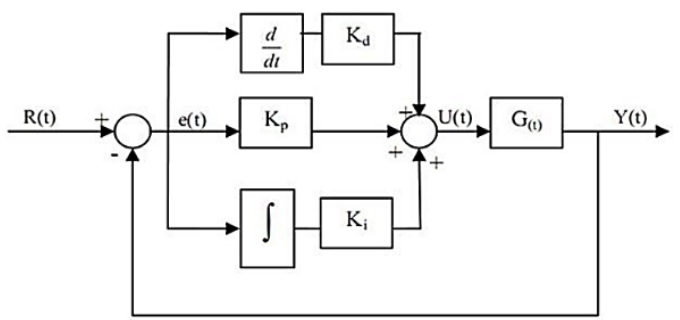

Gambar 4. Blok diagram kontrol PID. 


\section{F. Motor Servo}

Motor merupakan motor dengan sistem closed loop [11]. Motor servo dibekali rangkaian yang digunakan sebagai feedback motor servo. Karena dilengkapi dengan gear box maka torsi yang dihasilkan motor servo bervariasi tergantung jenis dan model yang digunakan. Motor servo yang digunakan mempunyai torsi sebesar $9.40 \mathrm{Kg}-\mathrm{cm}$. Motor servo ini digunakan untuk memutar besar katup gas pada kompor.

\section{G. Kontrol PID}

PID merupakan kontrol yang paling umum digunakan dalam merancang sebuah sistem kendali pada suatu plant untuk mencapai perilaku yang diinginkan, ditunjukkan pada gambar 4. Kontrol PID ini dapat digunakan sendiri-sendiri maupun secara keseluruhan. Kontrol yang cocok digunakan secara individu adalah kontrol Propotional (P) [12] atau dengan menggabungkan dua jenis kontrol yaitu Proportional dengan integral (PI) atau dengan menggunakannya secara keseluruhan (PID) [12]-[16].PERANCANGAN SISTEM

\section{H. Diagram Blok Sistem}

Secara keseluruhan diagram fungsional sistem dapat dilihat pada gambar 5. Push button digunakan sebagai pemilihan

tingkat kematangan. Kompor akan menyala dan motor DC sebagai pemutar wadah biji kopi akan berputar. Perubahan suhu yang terjadi akan dibaca oleh port ADC Arduino Due. Nilai tegangan yang telah dibaca oleh Arduino due akan dikonversi dalam besaran suhu. Suhu yang dihasilkan oleh mesin pemanggang akan dibandingkan dengan nilai set point yang telah ditentukan dalam program. Jika sensor suhu telah mencapai set point yang telah ditentukan maka proses telah selesai.

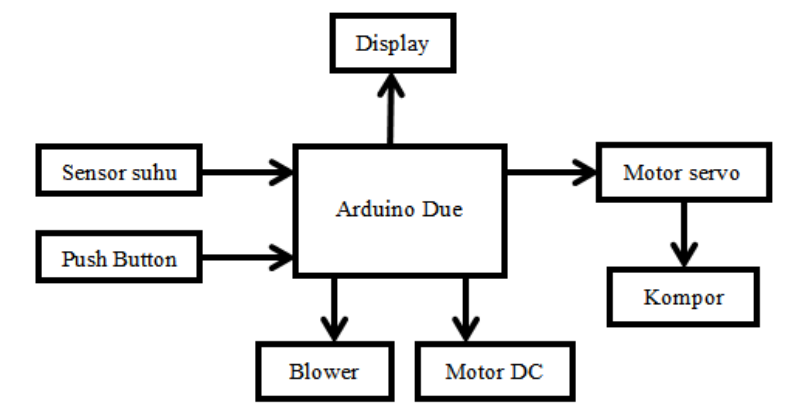

Gambar 5. Diagram Fungsional Sistem.

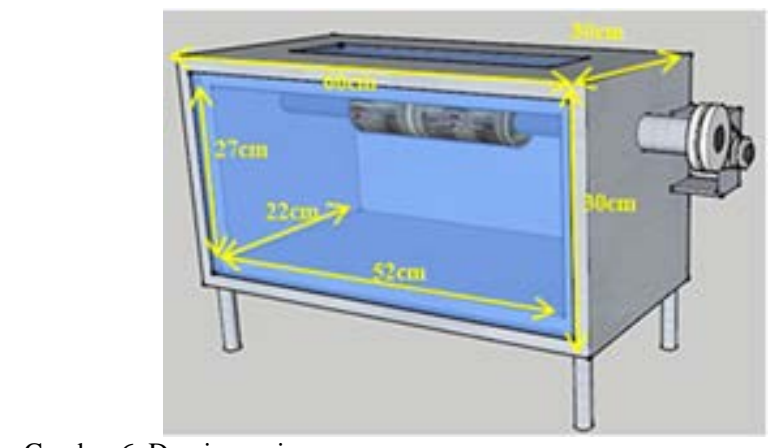

Gambar 6. Desain mesin pemanggang.

\section{Perancangan platform}

Pemanggang didesain menyerupai oven seperti yang ditunjukkan pada gambar 6 . Wadah biji kopi terletak didalam dengan poros terhubung motor DC. Dimensi pemanggang memiliki ukuran dibagian luar $60 \mathrm{~cm} \times 30 \mathrm{~cm} \times 30 \mathrm{~cm}$ sedangkan untuk ukuran bagian dalamnya yaitu $52 \mathrm{~cm} \times 27 \mathrm{~cm} \times 22 \mathrm{~cm}$. Sensor RTD diletakkan didalam poros sehingga masuk kedalam wadah biji kopi.

\section{J. Perancangan Software}

Perancangan software dilakukan untuk menentukan algoritma kematangan pemanggangan biji kopi, baik dalam tingkatan medium roast maupun dark roast. Perancangan software juga dirancang untuk pembacaan sensor RTD PT100 pada mikrokontroller. Flowchart program pada mikrokontroller Arduino Due ditunjukkan pada gambar 7. Sebelum memulai pemanggangan, terdapat pilihan menu 2 mode pemanggangan, yaitu mode pemanggangan medium roast dan dark roast. Setelah memilih mode pemanggangan maka selanjutnya adalah eksekusi algoritma program. Kematangan medium roast dibedakan dengan penentuan setpoint suhu yaitu $235^{\circ} \mathrm{C}$, sedangkan untuk dark roast yaitu pada $240^{\circ} \mathrm{C}$. Apabila set point suhu telah dicapai maka proses telah selesai.

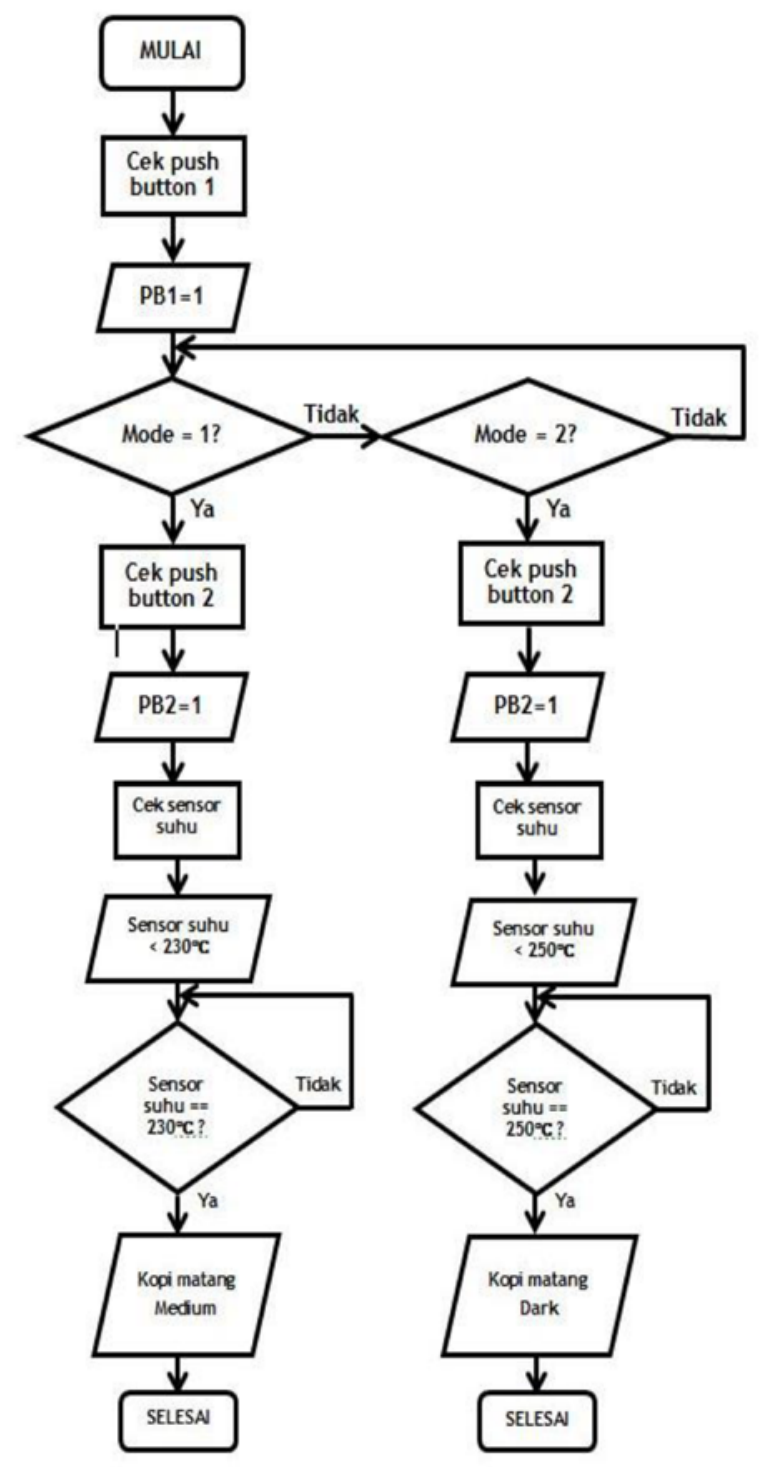

Gambar 7. Flowchart program sistem. 


\section{PENGUJIAN DAN PEMBAHASAN}

Hasil rancangan mesin pemanggang biji kopi dapat dilihat pada gambar 8. Beberapa pengujian dilakukan untuk mengetahui kinerja dari alat yang sudah dibuat.

\section{A. Pengujian sensor suhu}

Pada pengujian sensor suhu RTD PT100 dilakukan untuk mengetahui nilai tegangan keluaran. Tegangan keluaran yang dihasilkan oleh rangkaian pengkondisi sinyal akan dikonversi kedalam nilai ADC Arduino Due. Pengambilan nilai tegangan output dilakukan setiap kenaikan suhu sebesar $5^{\circ} \mathrm{C}$. Hasil pengukuran sensor suhu ini ditunjukkan pada Gambar 9.

\section{B. Pengujian Motor servo}

Pengukuran dan pengujian motor servo ditunjukkan pada tabel 3. Pergerakan motor servo diamati mulai dari $0-180^{\circ}$. Pengukuran dan pengujian dilakukan dengan memberi input pada motor servo berupa nilai duty cycle yang didapatkan dari persamaan (1).

$$
\text { Duty cycle }=\frac{T h}{T} \times 100 \%
$$

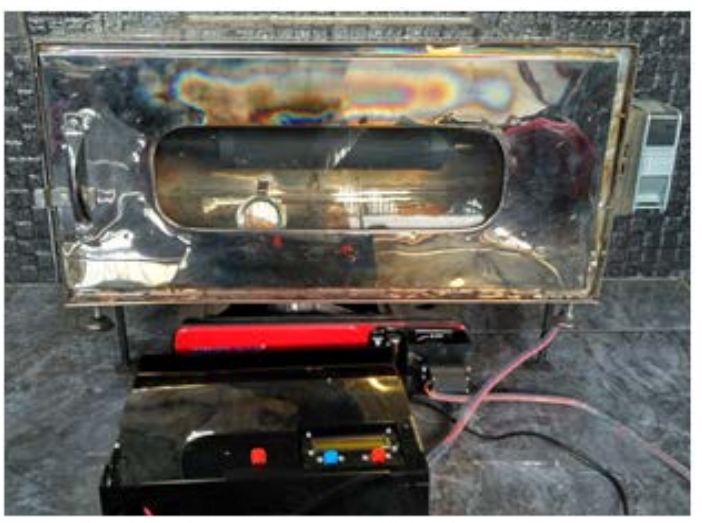

Gambar 8. Realisasi mesin pemanggang biji kopi.

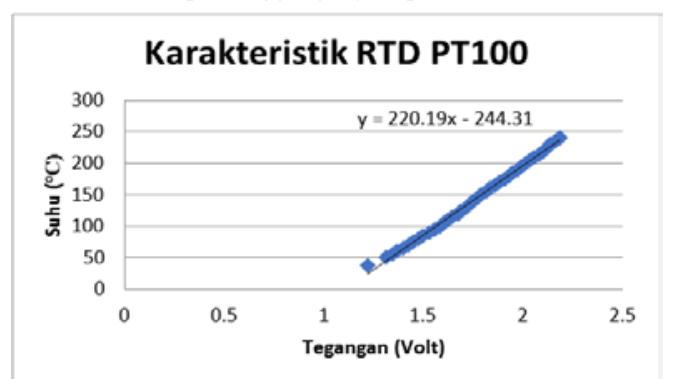

Gambar 9. Karakteristik sensor suhu.

Tabel 3.

Hasil pengujian motor servo.

\begin{tabular}{ccccc}
\hline \hline Duty Cycle & Th(ms) & $\begin{array}{c}\text { Hasil } \\
\text { (derajat) }\end{array}$ & $\begin{array}{c}\text { Teori } \\
\text { (derajat) }\end{array}$ & $\begin{array}{c}\text { Error } \\
(\%)\end{array}$ \\
\hline 5 & 1 & 0 & 0 & $0 \%$ \\
7.5 & 1.5 & 90 & 90 & $0 \%$ \\
10 & 2 & 180 & 180 & $0 \%$ \\
\hline \hline
\end{tabular}

Tabel 4.

Hasil perbandingan pemanggangan medium roast.

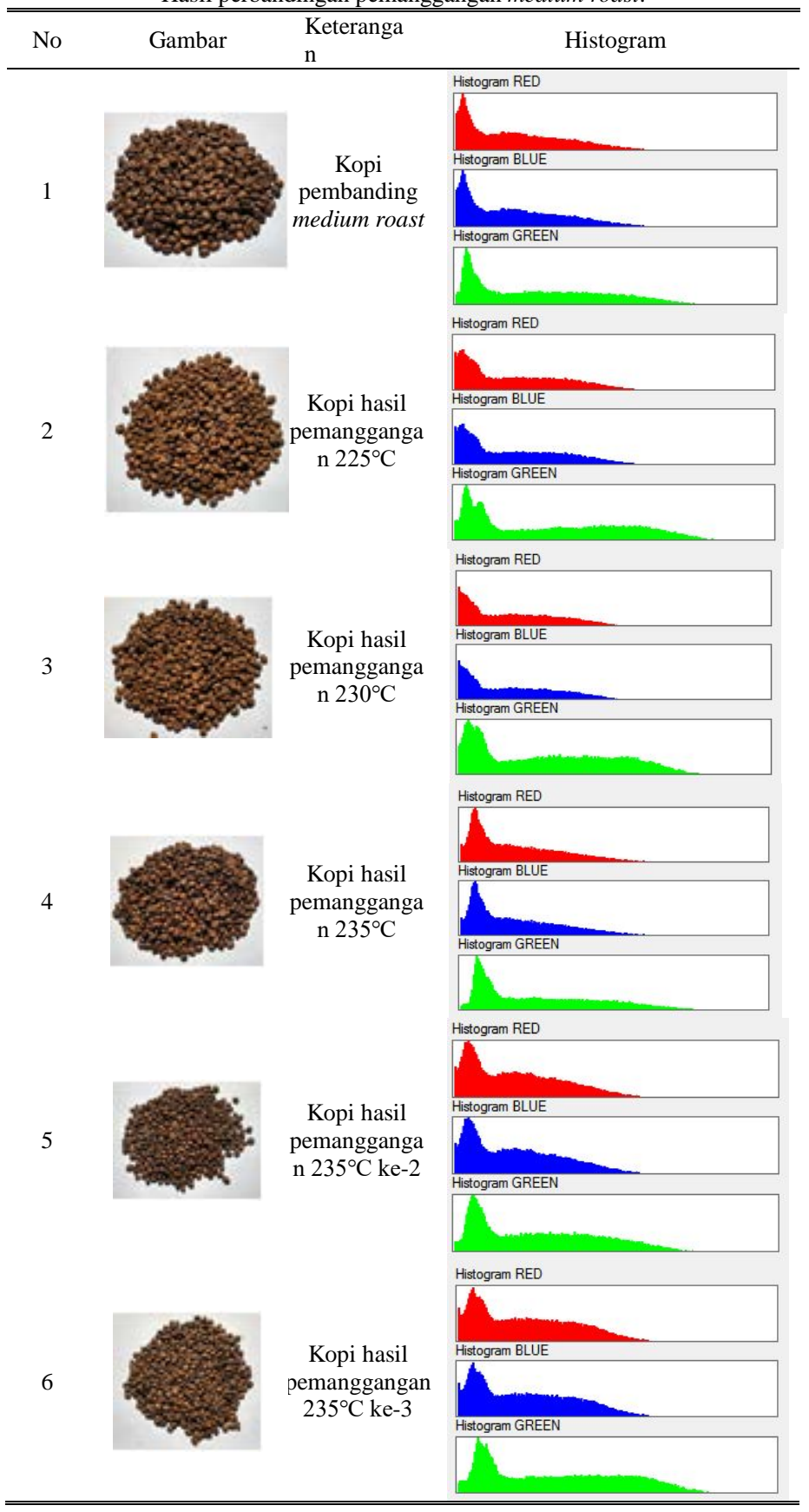

Tabel 5.

Hasil perbandingan pemanggangan dark roast.

\begin{tabular}{llcl}
\hline \hline No & Gambar & Keterangan & Histogram \\
\hline & & $\begin{array}{c}\text { Kopi } \\
\text { Kistogram RED } \\
\text { dark roast }\end{array}$ \\
\hline
\end{tabular}



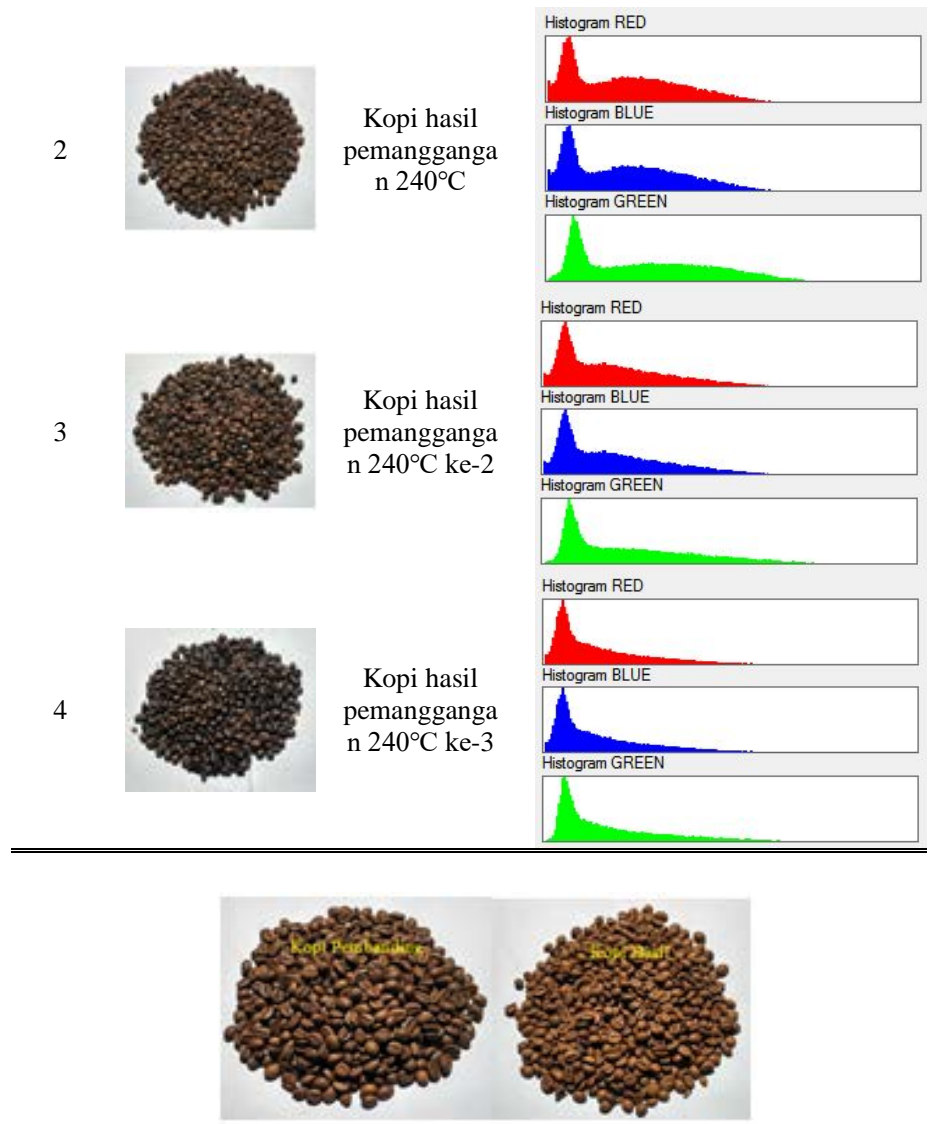

(a)

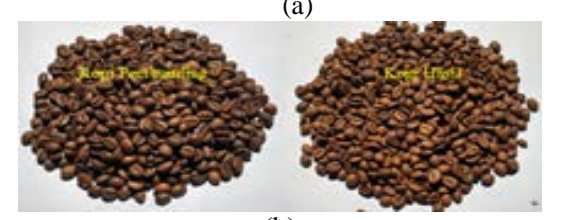

(b)

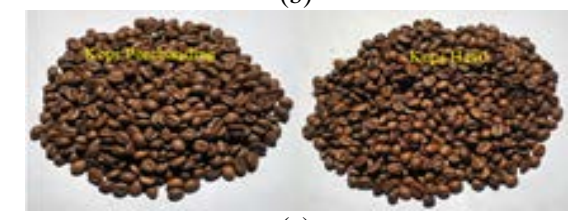

(c)

Gambar 10. Hasil pengujian sistem pada tingkat kematangan medium roast dengan set point suhu (a) $225^{\circ} \mathrm{C}$, (b) $230^{\circ} \mathrm{C}$, dan (c) $235^{\circ} \mathrm{C}$.

\section{Pengujian Sistem keseluruhan}

Pada pengujian sistem secara keseluruhan, set point dari tingkat kematangan kopi dirubah dan hasil dari pengujian akan dibandingkan dengan kopi pembanding dengan tingkat kematangan medium roast. Hasil dari pengujian sistem ditunjukkan pada gambar 10. Hasil citra yang diperoleh dapat dibandingkan dengan metode pemrosesan citra histogram RGB yang ditunjukkan pada Tabel 4 dan 5. Untuk pemberian set point $225^{\circ} \mathrm{C}$, hasil pemanggangan jauh lebih cerah dibandingkan pemanggangan dengan pemberian nilai set point sebesar $230^{\circ} \mathrm{C}$. Untuk set point $230^{\circ} \mathrm{C}$ warna yang dihasilkan terlihat lebih cerah dari pada proses pemanggangan dengan pemberian nilai set point $235^{\circ} \mathrm{C}$. Untuk set point $235^{\circ} \mathrm{C}$, warna biji kopi hasil pemanggangan oleh sistem sama dengan warna biji kopi pembanding.

\section{KESIMPULAN}

Pada penelitian ini telah dirancang dan dibuat mesin pemanggang biji kopi dengan suhu terkendali menggunakan Arduino Due dengan pemanas kompor gas portable. Wadah silinder untuk kopi terletak didalam dengan poros terhubung motor DC yang digunakan sebagai pemutar. Sensor suhu yang digunakan adalah RTD PT100. Hasil citra yang diperoleh dibandingkan dengan metode pemrosesan citra histogram RGB. Hasil pemanggangan biji kopi pada suhu $220^{\circ} \mathrm{C}$ mempunyai citra yang jauh lebih cerah dibandingkan dengan suhu $230^{\circ} \mathrm{C}$. Untuk set point $230^{\circ} \mathrm{C}$ warna yang dihasilkan terlihat lebih cerah dari pada suhu $235^{\circ} \mathrm{C}$. Untuk set point $235^{\circ} \mathrm{C}$, warna biji kopi hasil pemanggangan oleh sistem sama dengan warna biji kopi pembanding yang telah dinilai oleh seorang ahli.

\section{DAFTAR PUSTAKA}

[1] D. J. Perkebunan, "Statistik Perkebunan Indonesia."

[2] F. Winjaya, M. Rivai, and D. Purwanto, "Identification of Cracking Sound during Coffe Roasting Using Neural Network,” in International Seminar on Intelligent Technology and Its Application Institut Teknologi Sepuluh Nopember Surabaya, 2017, pp. 291-294.

[3] B. Lokker, "Coffee Roasts from Light to Dark - Coffee Crossroads," 2013.

[4] Legaldrugs Coffee, "Understanding the Coffee Roasting Legaldrugs Coffee.”

[5] Radi, R. Muhammad, and P. M. Hery, "Study on Electronic NoseBased-Quality Monitoring System for Coffe under Roasting,” J. Circuits, Syst. Comput., vol. 25, no. 10, pp. 1650116-1-1650116-19.

[6] Scott, Sarah, Brooke, and Bobby, "How to Roast Coffee for Beginners.”

[7] S. Kevin, An Enthusiast's Guide to Selecting, Roasting, and Brewing Exquisite Coffee. Massachusetts, 2010.

[8] S. C. A. of America, "Roast for Cupping." .

[9] R. K. Attri, B. K. Sharma, M. A. Shamshi, and V. P. Sharma, "Design Approach to use Platinum RTD Sensor in Snow Temperature Measurements,” J. Instrum. Soc. India, vol. 4, pp. 275-283, 2015.

[10] B. Sumantri and A. Wijayanto, "Pengaturan Posisi Motor Servo DC dengan Metode Fuzzy Logic.”

[11] P. D. Wijaya, M. Rivai, T. Tasripan, and T. Tasripan, "Rancang Bangun Mesin Pemotong Styrofoam 3 Axis Menggunakan Hot Cutting Pen dengan Kontrol PID,” J. Tek. ITS, vol. 6, no. 2, pp. A766770, Oct. 2017. 